\title{
Gap Versus Performance Based Measure of Pharmaceutical Education Service Quality: An Empirical Comparison
}

\author{
Kaushik Mandal, Hemant Gupta* \\ Department of Management Studies, National Institute of Technology-Durgapur, Durgapur, West Bengal, INDIA.
}

\begin{abstract}
Aim/Background: Whether service quality is measured by the gap between expectation and performance or by performance only. In quest of attaining answer of that query, the present research has taken an attempt to compare the efficacy of two varied orientations of service quality estimation empirically in pharmaceutical education service. Materials and Methods: We have surveyed randomly students of pharmaceutical graduation course of the six institutes. We have developed (Employing Exploratory Factor Analysis) and compared the models based on gap and performance scores with the help of indices relevant for Confirmatory Factor Analysis (CFA) and validated by carrying out Ordinary Least Squares (OLS) considering overall satisfaction as dependent and all explored items for measuring service quality as independent variables. Results: We are concluding this research work with certain dialectic outcomes. The outcomes clearly state that most of the criteria of model fitting, gap and performance score-based models have manifested resemblance. However, the performance score generates a better prediction of the overall satisfaction of the respondents. On the other way round, in the context of students of ranked institutes or students having experience, gap scores predict better the student's satisfaction. Implications: Present research is an effort to unfold the answer to the longstanding debate on SERVQUAL vs. SERVPERF. Any administrator who wants service excellence may be guided by context-specific application of quality measurement. The service researchers would be familiar with new ways of research analysis in the context of model effectiveness. Values: The work is new and pioneers to employ in academic service especially in pharmaceutical education.
\end{abstract}

Key words: Pharmaceutical Education, Service Quality Measurement, India, SERVQUAL, SERVPERF, Higher Education Service Quality.

\section{INTRODUCTION}

How to measure the quality of service? This question has emerged debates among management researchers since the development of the 'Service Quality Gap' model. ${ }^{1}$ The measurement of quality of service is always a subject for concern because service is far more complex than that of a product. Only in the case of very few services, quality is anticipated before its consumption. ${ }^{2}$ However, in the case of the majority of services, service quality is measured during or after the consumption. ${ }^{3}$ The service is difficult and multifarious since it is intangible, perishable, heterogeneous (Dependent on persons involved and the environment) and inseparable (Service producer and service consumer are embedded). ${ }^{4}$ Despite difficulties researchers have proposed the methodology of service quality measurement. Gronroos ${ }^{5}$ and Lewis and Booms are considered as a pioneer since they have extended the concepts of product quality offered by $\mathrm{Crosby}^{7}$ and others mentioning the quality is conformity to customer requirements (expectations). According to Gronroos $^{5}$ and Lewis and Booms, ${ }^{6}$ service quality can be measured how delivered service is matched closely with the expecta-
Submission Date: 01-01-2019; Revision Date: 06-02-2019; Accepted Date: 17-03-2019

DOI: 10.5530/ijper.53.3.75 Correspondence: Mr. Hemant Gupta Senior Research Scholar, Department of Management Studies, National Institute of Technology-Durgapur, Durgapur, West Bengal- 713209, INDIA.

Phone: +91-9883244275

E-mail: hemant.bpm13@ gmail.com

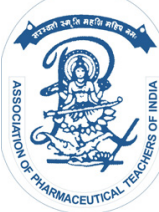

www.ijper.org 
tion of the customer. This definition of service quality is elaborated and reemployed further by Parasuraman et al. ${ }^{4,8-10}$ Actually, they have included a service process and outcome in measuring the quality of the service and offered a process based service quality gap model. ${ }^{9}$ Later on, they have also supplemented their initial work by offering five facets of service quality and that is well known as SERVQUAL., ${ }^{4-10}$ However, in all cases, their methods of measurement of service quality followed estimating the gap between expected and actual service delivered.

Acceptance of SERVQUAL is widespread since lion shares of service quality researches have been carried out in the similar line across the nations. On the other way around, critical evaluation of the SERVQUAL model is also observed and it leads by Cronin and Taylor, ${ }^{11}$ Carman ${ }^{12}$ and others. ${ }^{13-15}$ Critiques namely Cronin and Taylor ${ }^{11}$ and Carman ${ }^{12}$ opined that there is very less empirical and conceptual support in favor of considering service quality as a gap between expectation and perception (Actual). Hence, Cronin and Taylor ${ }^{11}$ carried out a comparison of SERVQUAL and their proposed SERVPERF (Performance only measure for service quality) in terms of empirical survey results. Cronin and Taylor ${ }^{11}$ have been influenced by opinions of Bolton and Drew, ${ }^{16}$ Churchill and Suprenant ${ }^{17}$ and others ${ }^{18}$ who preferred comparing actual performance with customer expectations to measure service quality. Carman ${ }^{12}$ who also influenced Cronin and Taylor, ${ }^{11}$ analyzed that a customer after experiencing a service could have a difference in scoring compare with the situations where he has not been exposed of the same and thus he argued expectation measurement has practically less effect on measuring service quality. Further, he argued that expectation differs in different service context and influences perceptions (Actual). Following Carman, ${ }^{12}$ Cronin and Taylor ${ }^{11}$ extended the critical appraisal of SERVQUAL model by proposing an alternative version namely SERVPERF and that was based on the assumption that service quality is determined only through perceived service performance, which is synonymous of perceptions (Actual) dimension of SERVQUAL.

There are a good number of researches since then who supports either SERVQUAL or SERVPERF again either conceptually or empirically, have been presented in tabular form (Table 1).

This table covers samples of the Sea of researches have been executed since the inception of service quality measurement research. Our objective is to demonstrate four vital observations as presented below:
- Despite many criticism researchers' dependence on SERVQUAL is beyond any question. Similarly, SERVPERF is equally accepted.

- Most importantly there is no such concrete evidence is available by which one can claim in general SERVPERF is better than SERVQUAL or vice versa.

- Neither service specific nor country wise (Economy and culture-specific) any general claim of superiority of SERVPERF over SERVQUAL or vice versa has been made.

Hence, the debate of efficiency of one over other still remain valid and may unfold the scope of examining the superiority of SERVPERF over SERVQUAL or vice versa in the field of yet to explored service like technical higher education particularly pharmaceutical education service. Further, service quality research is required in the developing nations where the quality of service is an emerging issue for the sustenance of technical and professional education since privately funded institutions involved in technical and professional education have experienced mushroom growth without proper screening of quality and industry are suffering for employable graduates. ${ }^{31}$ Pharmaceutical education is of no exception. We have been observing rapid growth of the institutes related to pharmaceutical education since the nineties of last century and this is mostly due to the huge enhancement of privately funded institutes. ${ }^{32}$ However, in the recent past Pharmaceutical education administration has been witnessing noticeable changes. Statistics of last six years that can be observed from an authenticated source namely AICTE dashboard ${ }^{33}$ has manifested clearly that enrolment of students in terms of approved capacities for B Pharm program in private entrepreneur led institutes are dwindling between 2012-13 and 2014-15. Later, because of the downsizing of approved intake (Capacity) by their administration, enrolment in terms of capacity is apparently increas-

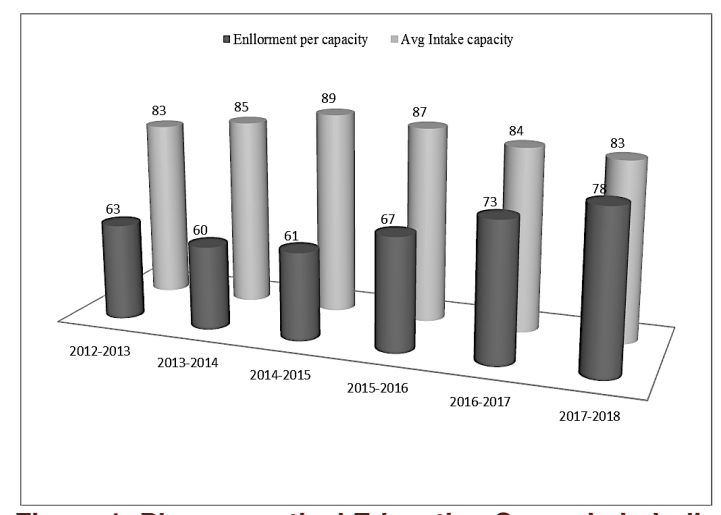

Figure 1: Pharmaceutical Education Scenario in India. 
Table 1: Industry-Wise Research Support for SERVQUAL and SERVPERF.

\begin{tabular}{|c|c|c|c|c|c|c|}
\hline SN & Authors & Year & Country & Insudtry & Type of Study & Concluding Remarks \\
\hline 1 & $\begin{array}{l}\text { Pakdil and } \\
\text { Aydin }^{19}\end{array}$ & 2007 & Turkish & Airline services & Empirical analysis & $\begin{array}{l}\text { Supported perceptions-minus-expectations } \\
\text { measurement of service quality (SERVQUAL) }\end{array}$ \\
\hline 2 & Gounaris $^{3}$ & 2005 & Greece & B2B services & Empirical analysis & $\begin{array}{l}\text { Supported perceptions-minus-expectations } \\
\text { measurement of service quality (SERVQUAL) }\end{array}$ \\
\hline 3 & $\begin{array}{l}\text { Badri et } \\
\text { al. }{ }^{20}\end{array}$ & 2005 & UAE & Telecommunications & Empirical analysis & $\begin{array}{l}\text { Supported perceptions-minus-expectations } \\
\text { measurement of service quality (SERVQUAL) }\end{array}$ \\
\hline 4 & $\begin{array}{c}\text { Kilbourne et } \\
\text { al. }^{21}\end{array}$ & 2004 & USA & Healthcare & Empirical analysis & $\begin{array}{l}\text { Supported perceptions-minus-expectations } \\
\text { measurement of service quality (SERVQUAL) }\end{array}$ \\
\hline 5 & Lam $^{15}$ & 2002 & China & Banking & Empirical analysis & $\begin{array}{l}\text { Supported perceptions-minus-expectations } \\
\text { measurement of service quality (SERVQUAL) }\end{array}$ \\
\hline 6 & Jiang et al. ${ }^{2}$ & 2000 & USA & Information systems & Empirical analysis & $\begin{array}{l}\text { Supported perceptions-minus-expectations } \\
\text { measurement of service quality (SERVQUAL) }\end{array}$ \\
\hline 7 & $\begin{array}{l}\text { Cook and } \\
\text { Thompson } 22\end{array}$ & 2000 & USA & Library services & Empirical analysis & $\begin{array}{l}\text { Supported perceptions-minus-expectations } \\
\text { measurement of service quality (SERVQUAL) }\end{array}$ \\
\hline 8 & $\begin{array}{l}\text { Quester } \\
\text { and } \\
\text { Romaniuk }^{23}\end{array}$ & 1997 & Australia & Advertising industry & $\begin{array}{l}\text { Comparative empirical } \\
\text { analysis between } \\
\text { SERVQUAL and } \\
\text { SERVPERF }\end{array}$ & $\begin{array}{l}\text { Supported the perceptions-minus- } \\
\text { expectations measurement of service quality }\end{array}$ \\
\hline 9 & $\begin{array}{l}\text { Kettinger } \\
\text { and Lee }{ }^{24}\end{array}$ & 1997 & & Information system & $\begin{array}{l}\text { Comparative empirical } \\
\text { analysis between } \\
\text { SERVQUAL and } \\
\text { SERVPERF }\end{array}$ & $\begin{array}{l}\text { supported the performance- } \\
\text { based measurement of service quality } \\
\text { (SERVPERF) }\end{array}$ \\
\hline 10 & $\begin{array}{l}\text { Cronin and } \\
\text { Taylor }^{25}\end{array}$ & 1994 & USA & Bank & $\begin{array}{l}\text { Comparative empirical } \\
\text { analysis between } \\
\text { SERVQUAL and } \\
\text { SERVPERF }\end{array}$ & $\begin{array}{l}\text { Supported the performance- } \\
\text { based measurement of service quality } \\
\text { (SERVPERF) }\end{array}$ \\
\hline 11 & $\begin{array}{l}\text { Brady et } \\
\text { al. }^{13}\end{array}$ & 2002 & USA & Banking & $\begin{array}{l}\text { Extension of Cronin } \\
\text { and Taylor (1992) by } \\
\text { doing a Comparative } \\
\text { empirical analysis } \\
\text { between } \\
\text { SERVQUAL and } \\
\text { SERVPERF }\end{array}$ & $\begin{array}{c}\text { Supported performance- } \\
\text { based measurement of service quality } \\
\text { (SERVPERF) }\end{array}$ \\
\hline 12 & $\begin{array}{l}\text { Mehta et } \\
\text { al. }{ }^{26}\end{array}$ & 2000 & Singapore & Retail chain & $\begin{array}{l}\text { Comparative Empirical } \\
\text { analysis between } \\
\text { SERVPERF and } \\
\text { another scale }\end{array}$ & $\begin{array}{c}\text { Supported performance-based measurement } \\
\text { of service quality (SERVPERF) in service- } \\
\text { oriented retail settings }\end{array}$ \\
\hline 13 & Smith ${ }^{27}$ & 1999 & UK & family-planning clinic & $\begin{array}{l}\text { Comparison between } \\
\text { SERVQUAL and } \\
\text { SERVPERF is } \\
\text { possible }\end{array}$ & $\begin{array}{l}\text { The purpose was different but Indirectly } \\
\text { Supported performance- } \\
\text { based measurement of service quality } \\
\text { (SERVPERF) }\end{array}$ \\
\hline 14 & $\begin{array}{l}\text { Angur et } \\
\text { al. }^{28}\end{array}$ & 1999 & India & Banking & $\begin{array}{l}\text { Comparative empirical } \\
\text { analysis between } \\
\text { SERVQUAL and } \\
\text { SERVPERF }\end{array}$ & $\begin{array}{l}\text { Slightly Supported performance- } \\
\text { based measurement of service quality } \\
\text { (SERVPERF) over SERVQUAL }\end{array}$ \\
\hline 15 & Lam $^{29}$ & 1997 & Hong Kong & Hospital & $\begin{array}{l}\text { Theoretical and } \\
\text { Empirical Analysis }\end{array}$ & $\begin{array}{l}\text { Supported performance- } \\
\text { Based measurement of service quality } \\
\text { (SERVPERF) }\end{array}$ \\
\hline 16 & $\begin{array}{l}\text { Taylor et } \\
\text { al. }^{30}\end{array}$ & 1994 & USA & $\begin{array}{l}\text { Health clubs, } \\
\text { Golf clubs, Movie } \\
\text { theatres, Dog tracks }\end{array}$ & $\begin{array}{l}\text { Empirical analysis of } \\
\text { the SERVQUAL scale }\end{array}$ & $\begin{array}{l}\text { Supported if the perceptions-minus- } \\
\text { expectations measurement of service quality } \\
\text { SERVQUAL when the individual items } \\
\text { comprising five dimensions are summed and } \\
\text { averaged otherwise not supported }\end{array}$ \\
\hline 17 & $\begin{array}{l}\text { Carrillat et } \\
\quad \text { al. }{ }^{1}\end{array}$ & 2007 & NA & NA & $\begin{array}{l}\text { Meta-analytical } \\
\text { comparison between } \\
\text { SERVQUAL and } \\
\text { SERVPERF }\end{array}$ & $\begin{array}{l}\text { Both scales are sufficient and equally satisfy } \\
\text { the concept of service quality. Both the scales } \\
\text { are equally popular (number of citation) } \\
\text { among the researchers }\end{array}$ \\
\hline
\end{tabular}


ing in the said period (Figure 1). Lowering of capacity is clearly understandable by falling of average intake capacity of the pharmaceutical institutes between 201516 and 2017-18. Hence, it might appear to be a supply shock when expected demand for Pharmaceutical workforce is increasing. ${ }^{34,35}$

Naturally, it is a pertinent question that why career aspirants are not considering B Pharm as an option when opportunities are well appreciated. ${ }^{36}$ Singh $^{37}$ has referred to the absence of quality training and research as a possible cause behind. Gupta and Mandal ${ }^{38}$ and Mandal and Gupta $^{39}$ have also opined identically. In the global context, Hold fold and Reinders ${ }^{40}$ have stated the need for students' judgment for offering quality service. All those opinions converge into a fact that there is a necessity of maintenance of service quality in the eyes of one of the important stakeholders namely students. Further, to offer the quality of service in pharmaceutical education we need to measure the same. Consequently, it is also relevant to understand for measuring service quality which principle whether gap based measurement ${ }^{41,42}$ or performance only measurement ${ }^{43,44}$ would be employed. Since both the principles of service quality measurement (Gap and performance based) have already been employed in existing research works vis-à-vis pharmaceutical education without comparing their efficiencies, hence, in the present research, we did the same. In addition, for the purpose of comparison, we have employed the methodologies employed by other leading research works vis-à-vis service quality measurement. Further, for the purpose of required elaboration of specific research query (Hypothesis), we have felt the necessity of reviewing the present state of research works in the field of technical higher education. Thus, in the next section, we have presented a discussion on the relevant research works of the same.

\section{Review of Literature}

Many authors ${ }^{41-44}$ have distinguished service offered by an educational institute with other services like banking, retail chain, hospital and healthcare, telecom and airline services. Education as service is more complex as intangibility, perishability, heterogeneity and inseparability all four service challenges are very much present in case of education as offered service. Moreover, in case of education, service encounters between student (and guardian) as service receiver and teachers (and administrative staffs) as service providers are infinite in numbers during the course tenure and thus, it is largely different from all other services mentioned. Said services like banking, retail chain, hospital and healthcare, telecom and airline services are having much less number of interaction between service providers and customers and consequential to this, chance of reshaping of expectation by lowering this is less. ${ }^{1}$ Since expectations are changed due to numerous interactions between service provider and customer, the plausibility of determining service quality by performance only may be high. We have reviewed literature in relation to higher education, which has been published in recent past (Last 20 years) and found some correlation between use of two different principles of service quality measurement and nature of higher education (Technical including management or General Education including physical education). Research works that have been focused on engineering and management educations $\mathrm{s}^{41,45-47}$ have employed a mostly gapbased measure of service quality. Alternatively, research articles ${ }^{43,48-53}$ that have been carried out in the field of general education (Including physical education) have used performance only measure predominantly with some exceptions. ${ }^{42,54} \mathrm{On}$ the other way around research works it can also be analyzed that there is no relation between countries where a survey of research taken place and use of said two principles of service quality measurement. From the systematic review, it is also found that most of the research works have developed a new construct for service quality measurement but none of them has emphasized on the comparative scientific analysis of the efficiencies of two measures of service quality measurement.

However, after scanning the research works we can scrutinize some pertinent micro observations as follows:

There are three different approaches of measurement of service quality in higher education and these are i) Gap based (Perception minus expectation and perception minus importance) and iii) perception only measurement of service quality.

Other than Abdullah ${ }^{52,53}$ no authors related to higher education service have compared between (or among) two (or more than two) constructs.

Abdullah $^{52,53}$ in both of his works compared between neither SERVPERF and SERVQUAL nor principle (Method) of measurements such as perceptions-minusexpectations and performance-based measurement of service quality. In fact, Abdullah ${ }^{52,53}$ in both of his works compared among SERVPERF, HEdPERF and HEdPERF-SERVPERF.

None of the researchers has worked on comparative efficiency of the principle of operation of two basic approaches to measuring service quality namely gap and performance based.

Furthermore, we have reviewed five research works (Covering all most majority works available) exclu- 
sively to pharmaceutical education and where we have observed that only in three works authors have constructed a model for quality measurement. Even this small number of research works are heterogeneous in principle of measurement, one ${ }^{39}$ followed perception minus expectation while Holdford et al. ${ }^{40,55}$ in two successive research works have taken a resort to performance only measure of the same. See Table 2 for a summary of the literature in relation to pharmaceutical education service quality.

Finally, after reviewing the literature, we understood that a less number of research works in relation to higher education that compared between the principles of measurement of service quality namely i) gap involving expectation and perception of service quality and ii) performance (perception based) only. But, it is very important to know which measuring principle is better. Therefore, we have decided to fulfill the gap in the existing literature with an emphasis in the context of pharmaceutical education service quality measurement since no research works have been carried out in said domain and we have already mentioned in the background section of the present work that the challenges in maintaining service quality of pharmaceutical degree education in the context of India.

Hence, in the present study, we worked with the following research query:

RQ: Which is the better principle of measuring service quality vis-à-vis pharmaceutical education? The principle of performance-based or performance minus expected (i.e. gap) based measurement of service quality.

Consequently, for the purpose of attaining this research query, it is necessary to know how to define better because definition must correlate with measurement. Existing literature suggested two different approaches. One researcher ${ }^{52,53}$ has opined for good fit structural model as the better measure of service quality. Abdul$1 \mathrm{ah}^{52,53}$ in both of his researches compared two different items for the measurement of service quality and therefore missed to compare the principles (Performance only and Performance minus Expectation) alone. For the purpose of overcoming this shortcoming in the present research, we have decided to work with one set of items that would be analyzed with two different principles for model building and further compared with appropriate fit indices employed for structural equation modeling. On the other way round, following Hodford and Reinders ${ }^{40}$ it can be opined that for pharmaceutical education because of its character is a non-discrete event and thus it is necessary to consider 'Overall Satisfaction' (OS) as an alternate measure of Overall Service Quality (OSQ). In relation to that, they have proposed to carry out ordinary least square regression considering OS as dependent and all dimensions of 'Education Service quality' as independent variables. The objective of carrying out OLS is to check goodness of model fit as cited by Hodford and Reinders ${ }^{40}$ whereas Abdul$\mathrm{lah}^{52,53}$ has proposed also to measure 'effect size' and relative importance by considering overall service quality as dependent variables and service quality dimensions of various models (SERVPERF and HEdPERV) as independent variables. Hence following all previous researchers, particularly Hodford and Reinders ${ }^{40}$ and Abdullah, ${ }^{52,53}$ we can refine our research queries into six subqueries as follows:

\begin{tabular}{|c|c|c|c|c|c|c|}
\hline SN & Authors & year & Country & $\begin{array}{l}\text { Area of Higher } \\
\text { Education }\end{array}$ & $\begin{array}{l}\text { A New Construct has been } \\
\text { developed? [YES (name of the } \\
\text { Construct) /Not Constructed] }\end{array}$ & Principle of Measurement \\
\hline 1 & $\begin{array}{l}\text { Mandal and } \\
\text { Gupta }^{39}\end{array}$ & 2018 & India & $\begin{array}{l}\text { Pharmacy } \\
\text { education }\end{array}$ & Yes (PESQ) & $\begin{array}{l}\text { Applied the principle of perceptions- } \\
\text { minus-expectations measurement of } \\
\text { service quality (SERVQUAL) }\end{array}$ \\
\hline 2 & Singh, $\mathrm{S}^{37}$ & 2014 & India & $\begin{array}{l}\text { Pharmacy } \\
\text { education }\end{array}$ & Not Constructed & $\begin{array}{c}\text { Conceptualized the Quality by Design } \\
\text { in Education }(\mathrm{QbDE}) \text { in pharmacy } \\
\text { education }\end{array}$ \\
\hline 3 & Gu et al. ${ }^{56}$ & 2014 & China & $\begin{array}{l}\text { Pharmacy } \\
\text { education }\end{array}$ & Not Constructed & $\begin{array}{l}\text { Proposed TQM, as a novel teaching } \\
\text { concept for pharmacy education }\end{array}$ \\
\hline 4 & $\begin{array}{l}\text { Holdford et } \\
\text { al. }{ }^{40,55}\end{array}$ & $\begin{array}{c}2001 \\
\text { and } \\
2003\end{array}$ & USA & $\begin{array}{l}\text { Pharmacy } \\
\text { education }\end{array}$ & $\begin{array}{c}\text { Yes } \\
\text { (ESQ-Educational Service } \\
\text { Quality) }\end{array}$ & $\begin{array}{l}\text { Applied the principle of performance- } \\
\text { based measurement of service quality } \\
\text { (SERVPERF) }\end{array}$ \\
\hline
\end{tabular}


$\mathbf{R Q}_{\mathbf{A}}$ : Which model fits better in terms of various fit indices? Perception minus expected (Gap) based model or perception (Performance only) based model.

$\mathbf{R Q}_{\mathrm{B}}$ : Whether Perception minus expected (Gap) based model is expectation biased or neutral to both (Perception and expectation).

$\mathbf{R Q}_{\mathrm{C}}$ : Which model produce better effect size when Overall Satisfaction (OS) is dependent (Criterion variable) and either perception (Performance only measure) or perception minus expectation (Gap measure) variables are independent variables?

$\mathbf{R Q}_{\mathbf{D}}$ : Which model produces a more noteworthy contribution (Number of statistically significant regression coefficients) of service quality variables when Overall Satisfaction (OS) is dependent (Criterion variable) and either perception (Performance only measure) or perception minus expectation (Gap measure) variables are independent variables?

$\mathbf{R Q}_{\mathbf{E}}$ : Which model produce better results in terms of effect size and number of statistically significant regression coefficients when moderating variables namely Selection of sample unit has been done from institutes having variety in performance as per NIRF framework and Overall Satisfaction (OS) is dependent (Criterion variable) and either perception (Performance only measure) or perception minus expectation (Gap measure) variables are independent variables?

$\mathbf{R Q}_{\mathbf{F}}$ : Which model produces better results in terms of effect size and number of statistically significant regression coefficients when moderating variables namely selection of sample unit has been done from students having variety in year of experience with their own institution and Overall Satisfaction (OS) is dependent (Criterion variable) and either perception (Performance only measure) or perception minus expectation (Gap measure) variables are independent variables?

Hence, in the next section, we have discussed the research process undertaken to get an answer to the above-stated research queries.

\section{Research Process}

At the outset, we have decided that we would like to resolve the said queries with the help of a sample survey on the students of pharmaceutical graduation course. It is also needless to mention why we have decided to work on that specific course of study. Gupta and Manda ${ }^{38}$ have emphasized the mushroom growth of pharmacy education after 1980. Mandal and Gupta ${ }^{39}$ have shown that the vicious cycle of unemployment and lack of industry readiness of the pharmacy graduates.

Further, we have seen there are a few research works have taken place on the measurement of service quality in pharmaceutical sectors. All the above three understandings converge towards the necessity of efficient service quality measurement by resolving the debate stated in Section 1 and hence motivated us to quest efficient measurement of same in pharmaceutical education. In addition, it was important to identify any service quality measurement construct from the pool of pharmaceutical research works that suffice our purpose. In the previous section, we have already critically analyzed that when to select which is better principle (Not the construct) of measuring service quality it is judicious to take a common construct employing which we need to compare both the principles (Performance only or gap measure). There are two major constructs namely Holdford and Patkar ${ }^{55}$ and Holdford and Reinders, ${ }^{40}$ both are based on performance only (SERVPERF) measure in the context of the USA and another one Mandal and Gupta ${ }^{39}$ in the context of India, is based on gap (SERVQUAL) measure. Since we are working in the context of India, we have selected the later one. This construct is comprised of 26 items under six factors. We have considered items only and have ignored the dimension as Van Herk et al. ${ }^{57}$ and Sultan et al..$^{58}$ observed different service quality measures when applied to different countries having separate economic conditions and culture produce modifications of dimensions mostly without having any change in the items.

Logically next in the research process, we have to set the 'Population of the research' and which we have planned to operationalize within West Bengal as it is within our geographic scope and the state is having a good share of pharmaceutical business alongside representative character of the Indian population. In West Bengal, there are 11 numbers of private pharmaceutical institutes covering 4000 to 5000 number of students. ${ }^{33}$ All of these 11 institutes are located in the south of West Bengal, so it is expected that they are having homogeneity of students. Thus, we have chosen randomly six institutes, which are located in four areas within South Bengal. All total 11 institutes are having 4212 number of enrolment for all four years. For the six institutes, this number comes down to $2083 .{ }^{33}$ We have understood following the work of Mandal and Gupta ${ }^{39}$ students of $1^{\text {st }}$ and $2^{\text {nd }}$ year having a different level of aspiration, so they need to be in different strata. Thus, we have chosen randomly from the enrollment list of second and fourth year that constitutes 983 numbers of students from said six institutes. According to sample size measurement ${ }^{59}$ (Describe minimum sample size for given confidence interval and margin of error) with 95 percent Confidence Interval (CI) and 10 percent Margin of Error (MOE) if population size is 4212 minimum size 
of sample should be 94 and if increase the CI up to 99 percent level it increases as 160 . However, for six institutes we have surveyed we can have a size of population 2083 and for this like, the previous figures are 92 and 154. If we are taking all students, of $2^{\text {nd }}$ year and $4^{\text {th }}$ year, the size of the population would be 983 and with 95 percent $\mathrm{CI}$ and 10 percent $\mathrm{MOE}$ the minimum size of the sample is 88 and if increase the CI up to 99 percent level it increases as 143 . We have randomly chosen 140 number of students from all six institutes equal number from both the years $\left(2^{\text {nd }}\right.$ and $4^{\text {th }}$ year), but initially, we get 124 number of replies which by repeated persuasion increases up to 130 . Our size of the sample is slightly short than the desired size of the sample which can be considered one of limitation of this work.

As already we have mentioned, we have decided to work with 26 items provided by Mandal and Gupta; ${ }^{39}$ we have prepared our questionnaire with those 26 items and organized questionnaire with two major parts. First major part asked the expectation of the students and we have presented another major part after some days, where we have enquired students about their perception on their present institute vis-a-vis said 26 items. We have offered a gap of some days between the executions of two parts of the questionnaire just to avoid pre-measurement error in the design. ${ }^{60}$

All the six research queries were examined by different statistical methods, For $\mathrm{RQ}_{A}$, the CFA with EFA is carried out and both the models have been compared in terms of various model fit indices.

For $\mathrm{RQ}_{\mathrm{B}}$, we have correlated gap score with expectation score as well as with perception score separately to understand whether said gap score is biased to any of them.

For $\mathrm{RQ}_{\mathrm{C} \text { and } \mathrm{D}}$, we have compared two models with the help of OLS regression, in both the model dependent variable has been Overall Satisfaction (OS) and for first model independent variables have been performance only (Perception) measure and for second model perception minus expectation (Gap) measure.

For $\mathrm{RQ}_{\mathrm{E} \text { and } \mathrm{F}}$ similar to the previous query, statistical analysis has been carried out, but the responses have been categorized (Based on either ranking or year of experiences of the student respondents) for the comprehensive analysis of the findings.

\section{Scheme, Results and Analysis}

We have initiated describing and analyzing results with the order of queries. In our research query 'A', we emphasized on the building of two confirmatory models based on relevant service quality items by employing correlation of the gap score (Performance minus expectation) and another by performance score. Before making the model confirm, it is necessary to develop the model through exploration and for this purpose 'Exploratory Factor Analysis' (EFA) with the help of method namely 'Maximum Likelihood' have been executed. Since the prerequisites for EFA are the 'Bartlett test of Sphericity'(BTS) that measures whether the correlation matrix is statistically varied from identity matrix or not and the Kaiser-Meyer-Olkin (KMO) test which measures the adequacy of the sample for executing EFA, have also been employed. A result of BTS is statistically significant that mean correlation matrix is significantly away from identity matrix (No correlations exist between any pair of variables) and thus we understood that within variables some degrees of correlations are present. The result of KMO is also satisfactory and thus we have carried out maximum likelihood-based factor analysis and found three-factor solutions with 60 percent of variance explained. It is also to note that we have ended with 10 items since in the process of purification we have not considered items having less than 0.50 correlations with any of the factor and items cross-loaded between two factors. ${ }^{61}$ Based on the items under specified factor we have identified service quality when measured regarding the gap between expectations subtracted from perception, is viewed with three facets namely Career driven policy, academic focus and updated views of the Management. All of them have high internal consistency since Cronbach alpha and Composite Reliability values are more than 0.75 in every occasion (Table 3). ${ }^{62}$

Next, the same procedures have been followed with the 'Perception Score' and found significant probability value for BTS test result alongside acceptable KMO value. In this case, again we have completed with three factors with almost similar items under the specified factor have been observed. Overall, 56 percent variations are explained with the satisfactory internal consistency of Cronbach's alpha (Range from 0.633 to 0.794 ), composite reliability (range from 0.735 to 0.803 and see the Table 4 for details).

Further we have examined the model by Confirmatory Factor Analysis (CFA) with an objective to understand which one of the above-stated duo is a best-fitted model in terms of various indicators namely i) Absolute fit measures ii) Incremental fit measures and iii) Parsimonious fit measures.61 In Table 5, it is observed that model based on gap score and model based on perception score both have either crossed or within the recommended value as suggested except the RMSEA value. Overall gap score-based model is better a little in terms of RMR value. 


\begin{tabular}{|c|c|c|c|c|}
\hline & \multirow[t]{2}{*}{ Kaiser-Meyer-Olkin (KMO) indexes } & \multicolumn{3}{|c|}{ Bartlett's Test of Sphericity } \\
\hline & & $x^{2}$ & df & $p$-value \\
\hline & 0.721 & 580.706 & 45 & 0.000 \\
\hline & Factor Name & $\begin{array}{l}\text { Career Driven } \\
\text { Policy }\end{array}$ & $\begin{array}{c}\text { Academic } \\
\text { focus }\end{array}$ & $\begin{array}{c}\text { Updated } \\
\text { views of the } \\
\text { Management }\end{array}$ \\
\hline $\mathrm{V} 1$ & $\begin{array}{l}\text { College/ Institute administration should help students for incubation } \\
\text { and entrepreneurial development. }\end{array}$ & 0.941 & & \\
\hline V2 & $\begin{array}{l}\text { I should get support from the institute and faculties to do innovative } \\
\text { and research work. }\end{array}$ & 0.713 & & \\
\hline V3 & Expert counseling should be arranged for student career development. & 0.666 & & \\
\hline V4 & College/Institute should be visible by advertisement and media activity. & 0.655 & & \\
\hline V5 & Career development seminars and workshops should be organized. & 0.565 & & \\
\hline V6 & College/Institute should provide all the information on its website. & 0.536 & & \\
\hline V7 & Semester courses should be completed on time & & 0.994 & \\
\hline V8 & I would like to get adequate* study materials & & 0.693 & \\
\hline V9 & $\begin{array}{c}\text { Classrooms should have (white/ Black/ Smart/ white and black/ white } \\
\text { and smart) board with LCD projector. }\end{array}$ & & & 0.899 \\
\hline \multirow[t]{4}{*}{ V10 } & Industry experts should be invited to take classes. & & & 0.667 \\
\hline & Total variance explains (60.91\%) & $29.49 \%$ & $16.77 \%$ & $14.65 \%$ \\
\hline & Composite Reliability & 0.842 & 0.834 & 0.767 \\
\hline & Cronbach's Alpha & 0.844 & 0.833 & 0.790 \\
\hline
\end{tabular}

In the case of query $\mathrm{B}$, our intention was to examine whether the gap score is related more with expectation score or not (or with perception score). This query gave birth to the following set of generic hypothesis:

$\mathbf{H}_{\mathrm{A}}{ }^{\text {exp: }}$ There is a significant correlation between expectation score and gap score for service quality item $i$.

$\mathbf{H}_{\mathbf{A}}{ }^{\text {perception: }}$ There is a significant correlation between perception score and gap score for service quality.

Where $i$ is equal to any one of the specified ten service quality items

We have taken the opinion of 130 respondents, on day one, for each of the 26 items respondents have assigned the expectation score and after some days, they have stated perception score. Further, we have calculated gap score (Perception-expectation). Now, we are having for each item three scores (Expectation, perception and gap score). Therefore, correlation analysis has been carried out between expectation and gap score vis-à-vis perception and gap score. Based on this, we have received results of 10 correlation values between gap score and expectation score. On the other side, ten correlation values between gap score and perception score and com- pare the number/s of significant correlation between stated situations.

In fact, we have found a significant correlation between expectation and gap score for all items, but it is only three for the case between perception and gap score (Table 6). This result clearly portraits the biases of gap score with expectation score.

Therefore, we conclude for research query B that for the purpose of measurement of the pharmaceutical education service quality gap score is relatively (Moderately) better measure compared with perception score.

In the case of research query $\mathrm{C}$ to $\mathrm{F}$, we have carried out Ordinary Least Square (OLS) regression where all the items for measuring service quality have been considered as independent variables and overall satisfaction has been employed as dependent variable since satisfaction is considered a better measure of manifestation of overall service quality by majority of the literature ${ }^{26-29}$ including the literature belonging to pharmaceutical ${ }^{40,55}$ and other education service quality measurement. ${ }^{48,52}$ We have executed OLS regression twice once with gap (Between expectation and performance) score and 


\begin{tabular}{|c|c|c|c|c|}
\hline & \multirow[t]{2}{*}{ Kaiser-Meyer-Olkin (KMO) index } & \multicolumn{3}{|c|}{ Bartlett's Test of Sphericity } \\
\hline & & $x^{2}$ & df & $p$-value \\
\hline & 0.560 & 507.028 & 45 & 0.000 \\
\hline & Factor Name & $\begin{array}{c}\text { Career } \\
\text { Driven Policy }\end{array}$ & $\begin{array}{l}\text { Academic } \\
\text { focus }\end{array}$ & $\begin{array}{c}\text { Updated } \\
\text { views of the } \\
\text { Management }\end{array}$ \\
\hline V1 & $\begin{array}{c}\text { My College/ Institute administration helps us with incubation and } \\
\text { entrepreneurial development. }\end{array}$ & 0.873 & & \\
\hline V2 & My Institute provides all the information on its website. & 0.808 & & \\
\hline V3 & $\begin{array}{l}\text { My College/Institute is visible to society through advertisement and } \\
\text { media activity. }\end{array}$ & 0.644 & & \\
\hline V4 & $\begin{array}{l}\text { I am getting proper support from the institute and faculties to do } \\
\text { innovative and research works. }\end{array}$ & 0.484 & & \\
\hline V5 & Here Semester courses are completed on time & & 0.988 & \\
\hline V6 & Students are getting required study materials. & & 0.580 & \\
\hline V7 & $\begin{array}{l}\text { In this College/Institute Career development, seminar and workshop } \\
\text { are organized. }\end{array}$ & & 0.482 & \\
\hline V8 & Here Industry experts are invited to take classes. & & & 0.997 \\
\hline V9 & $\begin{array}{c}\text { Our Classrooms have (white/ Black/ Smart/ white and black/ white and } \\
\text { smart) board along with LCD projector. }\end{array}$ & & & 0.541 \\
\hline V10 & Expert counseling is arranged for us for our career development. & & & 0.486 \\
\hline & Total variance explains $(56.74 \%)$ & $22.05 \%$ & $17.37 \%$ & $17.30 \%$ \\
\hline & Composite Reliability & 0.803 & 0.743 & 0.735 \\
\hline & Cronbach's Alpha & 0.794 & 0.673 & 0.633 \\
\hline
\end{tabular}

\begin{tabular}{|c|c|c|c|c|}
\hline Types of Fit & Model Fit Indexes & Recommended Values & $\begin{array}{c}\text { Model } \\
\text { based on } \\
\text { GAP Score }\end{array}$ & $\begin{array}{l}\text { Model based on } \\
\text { PERCEPTION Score }\end{array}$ \\
\hline \multirow{5}{*}{$\begin{array}{l}\text { Absolute Fit } \\
\text { Measures }\end{array}$} & Chi-Square/df & $\begin{array}{c}\text { Less than } 3.000 \text { for the nested } \\
\text { models }^{63}\end{array}$ & 2.479 & 2.604 \\
\hline & GFI (Goodness of Fit) & Greater than $0.8^{64}$ & 0.909 & 0.910 \\
\hline & AGFI (Adjusted GFI) & Greater than $0.8^{65}$ & 0.833 & 0.810 \\
\hline & RMSEA & Less than $0.10^{63}$ & 0.110 & 0.114 \\
\hline & RMR (Root Mean Square Residual) & Small RMR ${ }^{63}$ & 0.011 & 0.132 \\
\hline \multirow{2}{*}{$\begin{array}{l}\text { Incremental Fit } \\
\text { Measures }\end{array}$} & TLI (Tucker-Lewis Index) & Greater than $0.80^{64}$ & 0.880 & 0.850 \\
\hline & NFI (Normal Fit Index) & Greater than $0.80^{64}$ & 0.876 & 0.871 \\
\hline \multirow{2}{*}{$\begin{array}{l}\text { Parsimonious Fit } \\
\text { Measures }\end{array}$} & CFI (Comparative Fit Index) & Greater than $0.90^{63}$ & 0.920 & 0.913 \\
\hline & IFI (Incremental fit index) & Greater than $0.80^{64}$ & 0.922 & 0.916 \\
\hline
\end{tabular}

another with performance score. Later, for the purpose of queries $\mathrm{E}$ and $\mathrm{F}$, we have divided the sample unit into two sections i) students from the first fifty ranked institute under NIRF (National Institutional Ranking Framework by MHRD) ${ }^{66}$ and rest ii) students belong to beginning classes $\left(1^{\text {st }} / 2^{\text {nd }}\right.$ year $)$ and belong to experi- enced classes $\left(3^{\text {rd }} / 4^{\text {th }}\right.$ year $)$ and carried out OLS regression twice for each of the cases.

For the purpose of analyzing we have compared the OLS regression results between carried out with gap score and same with performance score. Overall it is seen that $R^{2}$, adjusted $R^{2}$ and 'effect size' is higher (Table 7) for the performance-based measure in comparison 
Table 6: Correlation between Gap Score and Expectation/Perception Score.

\begin{tabular}{|c|c|c|}
\hline \multicolumn{3}{|c|}{ Table 6: Correlation between Gap Score and Expectation/Perception Score. } \\
\hline Items & Correlation between Gap and Expectation score & Correlation between Gap and Perception score \\
\hline V1 & Significant $(p<0.05)^{*}$ & Significant $(p<0.05)^{*}$ \\
\hline V2 & Significant $(p<0.05)^{*}$ & Insignificant $(p>0.05)^{\#}$ \\
\hline V3 & Significant $(p<0.05)^{*}$ & Insignificant $(p>0.05)^{\#}$ \\
\hline V4 & Significant $(p<0.05)^{*}$ & Insignificant $(p>0.05)^{\#}$ \\
\hline V5 & Significant $(p<0.05)^{*}$ & Insignificant $(p>0.05)^{\#}$ \\
\hline V6 & Significant $(p<0.05)^{*}$ & Significant $(p<0.05)^{*}$ \\
\hline V7 & Significant $(p<0.05)^{*}$ & Significant $(p<0.05)^{*}$ \\
\hline V8 & Significant $(p<0.05)^{*}$ & Insignificant $(p>0.05)^{\#}$ \\
\hline V9 & Significant $(p<0.05)^{*}$ & Insignificant $(p>0.05)^{\#}$ \\
\hline V10 & Significant $(p<0.05)^{*}$ & Insignificant $(p>0.05)^{\#}$ \\
\hline Note: Significant ${ }^{*}$ means a $p$-value less than 0.05 and Insignificant" means a $p$-value more than 0.05 in the correlation analysis process. \\
\hline
\end{tabular}

\section{Table 7: Result of Regression Analysis with Significant Variables of the Different Approaches.}

Dependent Variable- Overall satisfaction of students from the pharmaceutical graduate degree course

\begin{tabular}{|c|c|c|c|c|}
\hline & & $\begin{array}{l}\text { Independent variables for Regression } \\
\text { analysis }\end{array}$ & Gap based model & $\begin{array}{l}\text { Performance only } \\
\text { model }\end{array}$ \\
\hline \multirow[t]{2}{*}{ Query C } & \multirow{4}{*}{$\begin{array}{l}\text { All Responded based } \\
\text { Model }\end{array}$} & $R^{2}$ & 0.475 & 0.507 \\
\hline & & Adjusted $R^{2}$ & 0.431 & 0.465 \\
\hline \multirow[b]{2}{*}{ Query D } & & Effect Size of Model* & 0.904 & 1.028 \\
\hline & & $\begin{array}{c}\text { Variables have a significant coefficient with } \\
\text { Overall satisfaction }\end{array}$ & 1 out of 10 & 5 out of 10 \\
\hline \multirow{8}{*}{ Query E } & \multirow{4}{*}{$\begin{array}{l}\text { Model based on } \\
\text { Responses from NIRF } \\
\text { ranked Institute }\end{array}$} & $R^{2}$ & 0.519 & 0.433 \\
\hline & & Adjusted $R^{2}$ & 0.434 & 0.330 \\
\hline & & Effect Size of Model* & 1.070 & 0.763 \\
\hline & & $\begin{array}{c}\text { Variables have a significant correlation with } \\
\text { Overall satisfaction }\end{array}$ & 2 out of 10 & 2 out of 10 \\
\hline & \multirow{4}{*}{$\begin{array}{l}\text { Model based on } \\
\text { Responses from rest of } \\
\text { the Institute }\end{array}$} & $R^{2}$ & 0.547 & 0.648 \\
\hline & & Adjusted $R^{2}$ & 0.446 & 0.613 \\
\hline & & Effect Size of Model* & 1.200 & 1.830 \\
\hline & & $\begin{array}{c}\text { Variables have a significant correlation with } \\
\text { Overall satisfaction }\end{array}$ & 1 out of 10 & 6 out of 10 \\
\hline \multirow{8}{*}{ Query F } & \multirow{4}{*}{$\begin{array}{l}\text { Model based on } \\
\text { Responses from } 1^{\text {st }} / 2^{\text {nd }} \\
\text { year students }\end{array}$} & $R^{2}$ & 0.402 & 0.543 \\
\hline & & Adjusted $R^{2}$ & 0.295 & 0.462 \\
\hline & & Effect Size of Model* & 0.672 & 1.188 \\
\hline & & $\begin{array}{c}\text { Variables have a significant correlation with } \\
\text { Overall satisfaction }\end{array}$ & 1 out of 10 & 4 out of 10 \\
\hline & \multirow{4}{*}{$\begin{array}{l}\text { Model based on } \\
\text { Responses from } 3^{\text {rd }} / 4^{\text {th }} \\
\text { year students }\end{array}$} & $R^{2}$ & 0.749 & 0.480 \\
\hline & & Adjusted $R^{2}$ & 0.694 & 0.367 \\
\hline & & Effect Size of Model* & 2.980 & 0.923 \\
\hline & & $\begin{array}{c}\text { Variables have a significant correlation with } \\
\text { Overall satisfaction }\end{array}$ & 2 out of 10 & 2 out of 10 \\
\hline
\end{tabular}

with same gap score (Query C). Moreover, for performance-based model five variables have been found whose regression coefficients are significantly away from zero (Table 7) and it is only one (Table 7) for the gap-based model (Query D). 


\begin{tabular}{|c|c|c|}
\hline $\begin{array}{l}\text { Series of } \\
\text { Queries }\end{array}$ & Outcomes of the study & Previous studies with similar findings \\
\hline Query A & $\begin{array}{c}\text { The efficacy of gap score based model is slightly better than performance } \\
\text { based model to measure the pharmaceutical education institutes service } \\
\text { quality. }\end{array}$ & $\begin{array}{l}\text { Mandal and Gupta; }{ }^{39} \text { Angell et al. } .^{42} \\
\text { Mahapatra and Khan; }{ }^{41}\end{array}$ \\
\hline Query B & $\begin{array}{l}\text { The gap score is biased with expectation score; the gap score is relatively } \\
\text { better measure compared to perception score. }\end{array}$ & $\begin{array}{l}\text { Carrillat et al. }{ }^{1} \\
\quad \text { Ladhari; } 8^{6} \\
\text { Llusar and Zornoza }\end{array}$ \\
\hline Query C & $\begin{array}{l}\text { The effect size is higher for perception only based model in comparison to } \\
\text { the gap score model. }\end{array}$ & Abdullah 52,53 \\
\hline Query D & $\begin{array}{l}\text { Perception based model has a greater number of significant regression } \\
\text { coefficient than gap score model. }\end{array}$ & Abdullah 52,53 \\
\hline Query E & $\begin{array}{l}\text { Gap based model is better to measure for top-ranked institutes rather } \\
\text { perception based model is more appropriate for non-ranked institutes of } \\
\text { pharmaceutical education. }\end{array}$ & Not done previously \\
\hline Query F & $\begin{array}{l}\text { If the service quality of pharmaceutical institutes is measured for } \\
\text { experienced students then gap-score model is better, else perception- } \\
\text { based model should be used. }\end{array}$ & Not done previously \\
\hline
\end{tabular}

Interesting observations have been originated when we divided the whole sample unit into two groups and carried out the OLS regression. First, we have segregated the whole respondents into two clusters that are responses from the students of NIRF ranked (First 100 rank holding institutes in pharmacy) institutes and rest of the students and executed OLS regression. These results have shown for measuring parameters like $R^{2}$, adjusted $R^{2}$ and effect size as proposed by $\operatorname{Cohen}^{67}$ gapbased score fits less erroneously with criterion variable (Overall satisfaction) and vice versa in case of students of other than the NIRF ranked institutes (Query E). Almost similar results are found for another parameter namely the number of the significant coefficient of the variables (Query E). In case of analyzing Query F we have segmented all the respondents in terms of their year of experiences with the course and have observed in case of beginners (Students of classes $1^{\text {st }}$ and $2^{\text {nd }}$ year) performance-based scores of ten service quality items (Independent variables) fits comparatively better with overall satisfaction (Dependent variable) considered as criterion variable (Table 7). In the case of experienced students, responses are just the opposite of the beginners (Table 7).

Overall resolving queries $\mathrm{E}$ and $\mathrm{F}$ we have observed apparently contrary statistical outcome though in deeper level it unfolds some thoughtful insight. Furthermore, this study has been found following similarity based on previous research outcomes (Table 8). In the next section of the concluding note, we have explained all of these in details.

\section{CONCLUSION}

Our findings unfolded some interesting observation. Service experience of the students belongs to high (within 100) NIRF ranked pharmaceutical institutes must differ from the students of the pharmaceutical institutes having no ranking and that is why service satisfaction of the students of high ranked institutes is dependent significantly on their gap score (Perception of the service after experiencing minus expectation of the service before the same). Just reverse has been seen for the students of non-rank institutes since they have either no expectation or they synchronize their expectation with actual (what they received) and therefore their service satisfaction is related mostly with the perception of the service after experiencing.

Similarly, students who have already experienced three and more year, eventually they became conscious about the difference between what they actually received and what they can be supposed to be received and thus it dictates their service satisfaction. Again, it is not the case of less experienced newly joined students. For them what they received, they believe in that and it directs their service satisfaction.

Hence, we have developed the following model of the relationship between service quality measurement and service satisfaction (as an outcome of service experience) where whether service quality measurement using gap score and service quality measurement employing performance score are moderated by 'quality service experience' and 'year of training experience' of the students. In the case of relatively high both of these factors, gap score is significantly related with service sat- 


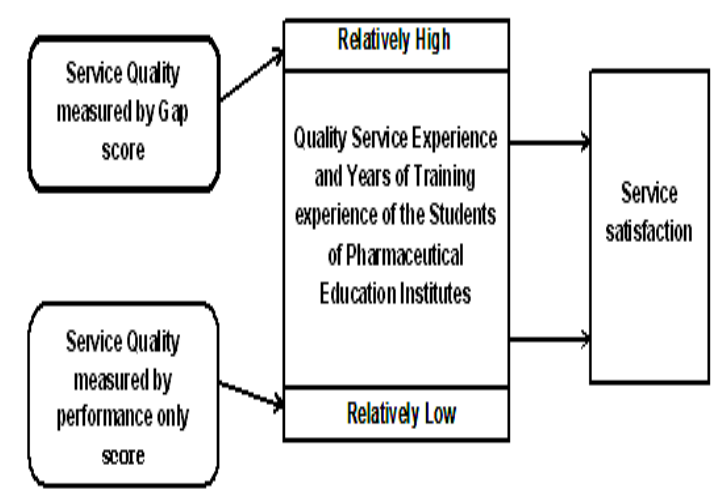

Figure 2: Pharmaceutical Education Service Satisfaction Model.

isfaction otherwise for relatively low of said two factors performance only score guides the service satisfaction (Figure 2).

\section{Implication of the Research}

The present research has taken an attempt to compare the efficacy of two varied orientations of service quality estimation empirically. It is an effort to unfold the answer of the long-standing debate SERVQUAL vs SERVPERF. Moreover, this research is a forerunner for resolving the said debate for pharmaceutical education. Academic administrators will be immensely benefitted as this work will provide insight into execution varied ways of measuring the quality of service with the different context of the institution. Service quality researchers may extend the present research problem (which service quality measurement techniques work better in their context?) in the circumstance of heterogeneous higher education institutes. Researchers would also be familiar with new ways of research analysis in the context of model effectiveness. Finally, our research offers academician a thoughtful resolution in relation to the direction of service quality measurement debate.

\section{ACKNOWLEDGEMENT}

Authors acknowledge the due support rendered by the authorities and the B. Pharm students of Pharmaceutical Educational Institutes of West Bengal for their support and participation in this research work. Authors also acknowledge the financial support offered by MHRD and NIT-Durgapur by providing institute fellowship to one of the co-authors for this work.

\section{CONFLICT OF INTEREST}

The authors declare no conflict of interest.

\section{ABBREVIATIONS}

EFA: Exploratory Factor Analysis; CFA: Confirmatory Factor Analysis; OLS: Ordinary Least Squares; RQ: Research Query; NIRF: National Institutional Ranking Framework.

\section{REFERENCES}

1. Carrillat FA, Jaramillo F, Mulki JP. The validity of the SERVQUAL and SERVPERF scales: A meta-analytic view of 17 years of research across five continents. International Journal of Service Industry Management. 2007;18(5):472-90.

2. Jiang $Y, L u$ WC. The impact of affect on service quality and satisfaction: The moderation of service contexts. Journal of Services Marketing. 2006;20(4):211-8.

3. Gounaris SP. Trust and commitment influences on customer retention: Insights from business-to-business services. Journal of Business Research. 2005;58(2):126-40.

4. Parasuraman A, ZeithamI VA, Berry LL. Servqual: A multiple-item scale for measuring consumer perc. Journal of Retailing. 1988;64(1):12-40.

5. Grönroos C. An applied service marketing theory. European Journal of Marketing. 1982;16(7):30-41.

6. Lewis RC, Booms BH. Emerging Aspect of service Quality in Emerging Perspectives on Services Marketing. Chicago: American Marketing Association En. 1983;100.

7. Crosby PB. Quality is free: the art of making quality certain. McGraw-Hill; London. 1979;305-9.

8. Parasuraman A, Berry LL, ZeithamI VA. Refinement and reassessment of the SERVQUAL scale. Journal of Retailing. 1991;67(4):420-51.

9. Parasuraman A, Zeithaml VA, Berry LL. A conceptual model of service quality and its implications for future research. The Journal of Marketing. 1985;49(4):41-50.

10. Parasuraman A, Zeithaml VA, Berry LL. Alternativ e scales for measuring service quality: a comparative assessment based on psychometric and diagnostic criteria. Journal of Retailing. 1994;70(3):201-30.

11. JrCronin JJ, Taylor SA. Measuring service quality: a reexamination and extension. The Journal of Marketing. 1992;56(3):55-68.

12. Carman JM. Consumer perceptions of service quality: An assessment of T. Journal of Retailing. 1990;66(1):33.

13. Brady MK, JrCronin JJ, Brand RR. Performance-only measurement of service quality: a replication and extension. Journal of Business Research. 2002;55(1):17-31.

14. Buttle F. SERVQUAL: Review, critique, research agenda. European Journal of Marketing. 1996;30(1):8-32.

15. Lam TK. Making sense of SERVQUAL's dimensions to the Chinese customers in Macau. Journal of Market-Focused Management. 2000;5(1):43-58.

16. Bolton RN, Drew JH. A longitudinal analysis of the impact of service changes on customer attitudes. The Journal of Marketing. 1991;55(1):1-9.

17. JrChurchill GA, Surprenant $C$. An investigation into the determinants of customer satisfaction. Journal of Marketing Research. 1982;19(4):491-504.

18. Woodruff RB, Cadotte ER, Jenkins RL. Modeling consumer satisfaction processes using experience-based norms. Journal of Marketing Research. 1983;20(3):296-304

19. Pakdil F, Aydın Ö. Expectations and perceptions in airline services: An analysis using weighted SERVQUAL scores. Journal of Air Transport Management. 2007;13(4):229-37.

20. Badri MA, Abdulla M, Al-Madani A. Information technology center service quality: Assessment and application of SERVQUAL. International Journal of Quality and Reliability Management. 2005;22(8):819-48.

21. Kilbourne WE, Duffy JA, Duffy M, Giarchi G. The applicability of SERVQUAL in cross-national measurements of health-care quality. Journal of Services Marketing. 2004;18(7):524-33.

22. Cook C, Heath F, Thompson RL. A meta-analysis of response rates in webor internet-based surveys. Educational and Psychological Measurement. 2000;60(6):821-36.

23. Quester $P$, Romaniuk S. Service quality in the Australian advertising industry: A methodological study. Journal of Services Marketing. 1997;11(3):180-92. 
24. Kettinger WJ, Lee CC. Pragmatic perspectives on the measurement of information systems service quality. Mis Quarterly. 1997;21(2):223-40.

25. Taylor SA, JrCronin JJ. SERVPERF versus SERVQUAL: Reconciling performance-based and perceptions-minus-expectations. Journal of Marketing: A Quarterly Publication of the American Marketing Association. 1994;58(1):125-31.

26. Mehta SC, Lalwani AK, Li HS. Service quality in retailing: relative efficiency of alternative measurement scales for different product-service environments. International Journal of Retail and Distribution Management. 2000;28(2):6272.

27. Smith AK, Bolton RN, Wagner J. A model of customer satisfaction with service encounters involving failure and recovery. Journal of Marketing Research. 1999;36(3):356-72.

28. Angur MG, Nataraajan R, JrJahera JS. Service quality in the banking industry: an assessment in a developing economy. International Journal of Bank Marketing. 1999;17(3):116-25.

29. Lam SS. SERVQUAL: A tool for measuring patients' opinions of hospital service quality in Hong Kong. Total Quality Management. 1997;8(4):145-52.

30. Taylor SA, Baker TL. An assessment of the relationship between service quality and customer satisfaction. Journal of Retailing. 1994;70(2):163-78.

31. Dhingra M. Higher Education and Professional Graduates' Employability Status-An Alarming Situation for India. Amity Global Business Review. 2017; 12(2):77-84.

32. Basak SC, Sathyanarayana D. Pharmacy education in India. American Journal of Pharmaceutical Education. 2010;74(4):68.

33. Pharmacy College Data. Available from: http://www.aicte-india.org/ dashboard/pages/dashboardaicte.php.

34. Annual reports of National Knowledge Commission of India. 2009.

35. Annual report. Department of Pharmaceuticals of India. Government of India-2015.

36. KPMG report. The human resource and skill requirement in pharmaceutical industry in India. 2013-2014.

37. Singh S. Quality by Design in Education- A Possible Futuristic Approach to Improve Current Status of Pharmaceutical Education in India. Indian Journal of Pharmaceutical Education and Research. 2016;50(1):39-45.

38. Gupta H, Mandal K. In search of service quality gap in pharmaceutical education: An alternative approach. International Journal of Applied Business and Economic Research. 2016;14(12):8508-83.

39. Mandal K, Gupta H. Service Quality Gap Measurement in Pharmaceutical Educational Institutes: An Empirical Analysis for Model Development. Indian Journal of Pharmaceutical Education and Research. 2018;52(3):351-62.

40. Holdford D, Reinders TP. Development of an instrument to assess student perceptions of the quality of pharmaceutical education. American Journal of Pharmaceutical Education. 2001;65(2):125-31.

41. Mahapatra SS, Khan MS. A framework for analysing quality in education settings. European Journal of Engineering Education. 2007;32(2):205-17.

42. Angell RJ, Heffernan TW, Megicks P. Service quality in postgraduate education. Quality Assurance in Education. 2008;16(3):236-54.

43. Gallifa J, Batallé P. Student perceptions of service quality in a multicampus higher education system in Spain. Quality Assurance in Education. 2010;18(2):156-70.

44. Teeroovengadum V, Kamalanabhan TJ, Seebaluck AK. Measuring service quality in higher education: Development of a hierarchical model (HESQUAL). Quality Assurance in Education. 2016;24(2):244-58.

45. Kumar S, Dash MK. The INSTAQUAL scale: An instrument for measuring service quality of management institutions. International Journal of Services, Economics and Management. 2014;6(4):377.

46. Mandal K, Banerjee CK. A search for measuring quality in engineering education: An empirical study. Zenith International Journal of Business Economics and Management Research. 2012;2(3):50-67.
47. Joseph M, Joseph B. Service quality in education: a student perspective. Quality Assurance in Education. 1997;5(1):15-21.

48. Latif KF, Latif I, Farooq SU, Ullah M. In search of quality: Measuring Higher Education Service Quality (HiEduQual). Total Quality Management and Business Excellence. 2017;1-24. (DOI: 10.1080/14783363.2017.1338133)

49. Sultan $\mathrm{P}$, Yin $\mathrm{WH}$. Service quality in a higher education context: an integrated model. Asia Pacific Journal of Marketing and Logistics. 2012;24(5):755-84.

50. Senthilkumar N, Arulraj A. SQM-HEI-determination of service quality measurement of higher education in India. Journal of Modelling in Management. 2011;6(1):60-78.

51. Yildiz SM, Kara A. The PESPERF scale: An instrument for measuring service quality in the School of Physical Education and Sports Sciences. Quality Assurance in Education. 2009;17(4):393-415.

52. Abdullah F. HEdPERF versus SERVPERF: The quest for ideal measuring instrument of service quality in higher education sector. Quality Assurance in Education. 2005;13(4):305-28.

53. Abdullah F. Measuring service quality in higher education: HEdPERF versus SERVPERF. Marketing Intelligence and Planning. 2006;24(1):31-47.

54. Marimon F, Mas-Machuca M, Berbegal-Mirabent J, Llach J. Univ Qual: A holistic scale to assess student perceptions of service quality at universities. Total Quality Management and Business Excellence. 2017;30(1-2):1-7. (DOI: 10.1080/14783363.2017.1302795)

55. Holdford D, Patkar A. Identification of the service quality dimensions of pharmaceutical education. American Journal of Pharmaceutical Education. 2003;67(4):108.

56. Gu X, Song X, Dong M, Sun H, Li J, Liu G, et al. Implementation of Total Quality Management in Higher Pharmaceutical Education: Opportunity and Challenge. Indian Journal of Pharmaceutical Education and Research. 2015;50(1):34-8

57. Herk HV, Poortinga YH, Verhallen TM. Equivalence of survey data: Relevance for international marketing. European Journal of Marketing. 2005;39(3/4):35164.

58. Sultan F, JrSimpson MC. International service variants: airline passenger expectations and perceptions of service quality. Journal of Services Marketing. 2000;14(3):188-216.

59. Sample size calculation. Available from: http://research-advisors.com/tools/ SampleSize.htm.

60. Sureshchandar GS, Rajendran C, Anantharaman RN. A holistic model for total quality service. International Journal of Service Industry Management. 2001;12(4):378-412.

61. Hair J, Black B, Babin B, Anderson R, Tatham R. Multivariate data analysis, $7^{\text {th }}$ edition. Upper Saddle River, NJ: Prentice-Hall. 2009;97-125.

62. Field A. Discovering statistics using SPSS. SAGE Publications Ltd. London. 2001;339-46.

63. Schreiber JB, Nora A, Stage FK, Barlow EA, King J. Reporting structural equation modeling and confirmatory factor analysis results: A review. The Journal of Educational Research. 2006;99(6):323-38.

64. Carlson M, Mulaik SA. Trait ratings from descriptions of behavior as mediated by components of meaning. Multivariate Behavioral Research. 1993;28(1):111-59.

65. Madsen HO, Krenk S, Lind NC. Methods of Structural Safety. Pren-tice-Hall, Inc, Englewood Cliffs, NJ. 1986;120-35.

66. Pharmacy College Ranking Data. Available from: https://www.nirfindia. org/2017/PharmacyRanking.html.

67. Cohen J. A power primer. Psychological Bulletin. 1992;112(1):155.

68. Ladhari R. A review of twenty years of SERVQUAL research. International Journal of Quality and Service Sciences. 2009;1(2):172-98.

69. Carlos BLJ, Camisón ZC. Validity and reliability in perceived quality measurement models: an empirical investigation in Spanish ceramic companies. International Journal of Quality and Reliability Management. 2000;17(8):899-918 


\section{SUMMARY}

- The study has taken an attempt to compare the efficacy between 'Gap' and 'Performance' orientations of service quality assessment empirically with special emphasis on pharmaceutical education service.

- The 'Goodness of fit' for models developed by both the orientation has been compared with the help of CFA indices.

- The results also validated by carrying out model fitting through OLS regression technique considering overall satisfaction as dependent and all explored items for measuring service quality as independent variables for each of the model and compared in terms of $R^{2}$ and significance of regression coefficients.

- The outcomes of analysis state that most of the criteria of model fitting, gap and performance scorebased models have manifested equal outcome. However, the performance score generates a better prediction of overall satisfaction of the respondents from Pharmaceutical education institutes.

- The gap score model predicts better overall satisfaction in the context of students of NIRF ranked pharmacy institutes or students having higher experience in course study.

\section{ABOUT AUTHORS}

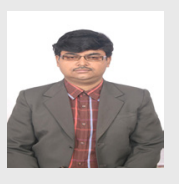

Dr. Kaushik Mandal: Is working as a capacity of Associate Professor in the Department of Management Studies, National Institute of Technology-Durgapur. He has done his master and doctoral work in business administration. He is an author of several peer-reviewed publications in the field of service marketing, brand management, distribution channel. He has reach experience of corporate and entrepreneurial training.

Mr. Hemant Gupta: Is associated as senior research scholar in the Department of Management Studies, National Institute of Technology-Durgapur. He is holding Masters in Business Administration and Bachelors in Pharmacy and currently he is pursuing $\mathrm{PhD}$ in Management from NIT-Durgapur. Before joining in the PhD program he has worked in the pharmaceutical industry for more than five years.

Cite this article: Mandal K, Gupta H. Gap Versus Performance Based Measure of Pharmaceutical Education Service Quality: An Empirical Comparison. Indian J of Pharmaceutical Education and Research. 2019;53(3):421-34. 